\title{
¡No pasarán! The Battle of Cable Street as a Political Context for Youth Activism in Fiction for Children and Young People
}

\author{
Kimberley Reynolds
}

What has come to be known as "The Battle of Cable Street" was a working-class uprising that took place in the East End of London on October 4, 1936. Over the decades, it has taken on legendary significance in the UK because it is regarded as a defining moment in British opposition to fascism that helped to shape Britain's role in World War II. That claim is exaggerated; nevertheless, the events in Cable Street saw approximately 250,000 antifascist demonstrators from a wide range of backgrounds converge to prevent Oswald Mosley and 3,000 members of his British Union of Fascists from marching through the Jewish section of the East End. Their permission to march was guaranteed by the British Home Office despite the fact that two days before the event the Jewish People's Council submitted a petition in objection that carried more than 100,000 signatures. In line with the Home Office decision, while Mosley and his "Blackshirts" may have been the reason for this huge and sometimes violent protest, the actual "battle" was largely between the protesters and the 6,000 police-representatives of the State-who were protecting Mosley's and his followers' right to march. ${ }^{1}$ That fact has become more prominent in recent accounts of the event as has the multicultural nature of the protesters. This revised emphasis reflects changing cultural attitudes to the State, to the police, and to the role of children in political events, all of which have affected the way the story is represented in writing for children and young people.

Such adjustments to accounts of what happened in the Cable Street area are only to be expected. As Walter Benjamin pointed out in his 1942 essay, "On the Concept of History," retellings of significant historical events, or what he referred to as "states of emergency" / "moments of danger" (qtd. in Jessop 648), belong not to their own time but to all times, and are constantly reinterpreted in line with new evidence and changed ways of thinking (Osborne and Matthew). Each new iteration is at least as much about the time of the retelling as it is about the moment when an event occurred. Often this is especially so when an incident from the past is represented to younger readers, since given the age of their audience and likely lack of familiarity with many 
aspects of the past, writers generally provide a considerable quantity of interpretation and background information that is inevitably informed by current thinking. Additionally, an event or historical moment will usually have been selected because an author sees in it connections with the present that may help readers better understand or question their own time.

Benjamin's thinking about children and the child figure in culture is also relevant to this discussion. During the 1920s and 1930s, the years leading up to and including The Battle of Cable Street, he was writing plays and making radio broadcasts for children and young people with a view to encouraging them to become socially engaged and active (Zipes 2). Beyond the potentiality of real children, however, Benjamin endowed the symbolic child figure with messianic properties, meaning the capacity to claim and redeem what has been lost in culture, foremost of which he regarded as a sense of collective experience (Ross). The turn of the millennium, a time of widespread uncertainty about the future, saw a similar movement in fantasy writing for children and young people. For instance, a number of critics have identified Buffy the Vampire Slayer, Harry Potter, Katniss Everdeen, and Lyra Belacqua as messianic figures, destined to save their worlds. ${ }^{2}$ However, where Benjamin looked to the messianic child figure to help bring about specific and possible social changes in the real world, the protagonists of these popular series are charged with saving whole worlds from existential threats of many kinds. The distinction between these two versions of the messianic child affects the kind of writing directed to young readers. Writers in the Benjaminian tradition produce what has been referred to as "radical children's literature," meaning writing that helps to promote new visions of society and encourages readers to prepare themselves for the work of bringing about change. ${ }^{3}$ By contrast, the messianic fantasies express a collective sense of anxiety and point to threats, but they have no practical goals.

As the examples discussed below show, stories about The Battle of Cable Street are in the Benjaminian messianic tradition. They reclaim a moment of collective action, and in doing so, they also call attention to the way the postwar emphasis on the rights of children to be protected and cared for largely suppressed ideas of the child figure as an agent of social redemption. ${ }^{4}$ In line with changes to the understanding of what childhood should be like, both real children and the symbolic child figure were placed outside political action, including in writing for children and young people. Cable Street narratives reinscribe the child figure in the political landscape. 
For those on the liberal-to-left side of politics, The Battle of Cable Street is regarded as a moment when democracy worked, with "the people" providing a corrective to oppressive ideologies and state institutions. For that reason, left-leaning groups mark its anniversaries and evoke Cable Street at times when democracy is perceived to be under threat. For example, after Margaret Thatcher's Conservative government came to power in 1979, the twenty-fifth anniversary celebrations of the Battle included painting a huge mural on the side of the town hall in Cable Street. Children's literature was slow to critique the Thatcher era, but by 1990, when the New Labour government entered Downing Street, children's books across all genres had begun to explore the impacts on Britain and its welfare state of fifteen years of Thatcherism, with its commitment to privatization, free-market economics, and nationalism. From that time, the events in Cable Street have featured in several works for children. Examining how Cable Street as a setting is used across a range of books gives an indication of how far British children's literature is engaged in helping today's young readers understand themselves as political beings, and to believe that it matters what populations and individuals, whatever their age, do and do not do.

\section{Where Have All the Children Gone?}

The political permutations that fed into and culminated in The Battle of Cable Street are complicated: it was about fascism, but also about class, economics, migration, and schisms within various political groupings. Of particular interest to this discussion is that the participation of children and young people in this "moment of danger" has largely been erased from the versions told to them. This absence is evidence of the suppression of the messianic/activist child in postwar Britain since the young were certainly among those who opposed Mosley and the Blackshirts' police guard. For instance, eyewitness reports and testimony from those who were in Cable Street and the surrounding area on the day agree that children were encouraged to throw marbles under the hooves of the mounted policemen's horses. This was evidently an effective strategy as the consequences are mentioned in many accounts, including this description given by Bill Fishman, who was a fifteen-year-old participant: "Suddenly, the horses' hoofs were flying and the horses were falling down because young kids were throwing marbles" (qtd. in Gillan). In other statements, girls tell how they went out armed with pockets full of pepper dust to throw in the faces of the 
fascists (Valman). Children also climbed up lampposts to see over the crowds and direct the protesters to places where the police presence was weak (Jacobs). Two juveniles were among the eighty-five people arrested at the scene, and a number of others had to be treated for injuries (Demissie and Iglikowski).

More important even than these acts by individual children and youths, however, is the mass attendance of young political activists from all over the country. This came about because the Young Communist League (YCL) had arranged for a major antifascist rally, intended to raise money for the Republicans in Spain, to be held on the same day in London's Trafalgar Square. ${ }^{5}$ At the last minute, this rally was canceled and the participants, many of whom had traveled long distances to attend, were redirected to the streets where the Blackshirts were scheduled to march. Evidence of the last-minute nature of the change is apparent in surviving leaflets for the original event; as there was not time to design and print new leaflets, the existing ones were overprinted with directions to go to the East End. In this way, a huge youth contingent swelled the numbers present in and around Cable Street. A second result of the YCL decision to join in the protests against Mosley's march is the extent to which The Battle of Cable Street is bound up with the history of British involvement in the Spanish Civil War, which also attracted a great many young volunteers. In fiction for children and young people, the two events are almost always combined.

\section{Children as Activists in 1930s Britain}

The Battle of Cable Street was not the first time that children on the left of society had taken to the streets of Britain as part of political protests, but it was and remains the most tumultuous. A notable earlier example of youth activism is a strike begun in 1914 when schoolgirl Violet Potter led her schoolmates in a walkout to support their Christian Socialist teachers. What became known as the Burston School Strike resulted in "temporary" teaching arrangements that lasted until 1939, by when most of the teachers had retired and all the original children had long ago completed their educations. This child-orchestrated strike is the longest in British history (Rosen). More usually, children's political street activities took the form of pageants, tableaux, short plays, and processions on themes and subjects such as peace, internationalism, and reforming the economy. Such performances were often scripted by adults; they make full use of the symbolic associations between 
childhood and social regeneration, and together constitute a politically motivated subgenre of children's literature. In the 1930s, these were complemented by left-wing children's publications that exhorted children to become activists by celebrating the contributions of children to uprisings in the past, honoring children's bravery in opposing fascism at home and abroad, and encouraging them to prepare for the revolution those on the left believed was soon to come.

Such examples of radical children's literature, imbued with a Benjaminian sense of the messianic child as both protagonist and reader, fill the pages of The Red Corner Book for Children (1931) and Martin's Annual (1935). Indeed, the entire contents of these publications were aimed at encouraging children to think politically and to work to fight injustice and inequality. For instance, "The Boys of Paris" in The Red Corner Book for Children tells how in 1871 children helped to overthrow the government and establish the briefly lived Paris Commune. Martin's Annual includes the inspiring story "Red Front" by Michael Davidson, which tells of the bravery of two boys who try to raise awareness of Nazi atrocities through small acts of subversion and resistance. ${ }^{6}$

In the 1930s, the cultural figure of the messianic child existed alongside real infants, children, and young people who were suffering from the effects of economic deprivation. As Benjamin saw it, the revolution to come would be inspired by the image of a future in which such children were liberated from oppression and want (Jessop 647). In the weeks following The Battle of Cable Street, the symbolic capital accrued by the redeemer-victim child was used to considerable effect: infants and children were very much in evidence in demonstrations demanding improvements to the living conditions of the poor, such as rent strikes in cities across the UK. These were a direct spin-off from the events in Cable Street designed to prevent fascists from recruiting in areas beset by problems arising from poverty, not least of which was high rents for atrocious housing.

Most of these activities and the youth publications that supported them are long forgotten, but The Battle of Cable Street has been kept alive in the cultural memory, including through children's literature. For the most part, its use as a political context in children's books corresponds to periods of political and social change or anxiety about the future. Unsurprisingly, these are also the times of greatest interest in the legacies of Benjamin's philosophies. Jack Zipes, for instance, notes that Benjamin's work for and about children in the 1920s and 1930s stimulated new forms of children's culture at the end of the 1960s, a 
time marked by antiwar, civil rights, and feminist protests. He made this observation in a 1988 review of recent developments in West and East German children's literature; a few months later, a series of upheavals culminated in the fall of the Berlin Wall.

The decision to set a children's book in Cable Street constitutes a Benjaminian use of the past by connecting readers to earlier events in ways that motivate them to act in the present and so redeem the future. In other words, these books address children as potential activists, though the nature and extent of their activism varies in line with such factors as the age of readers, topical concerns, and market conditions at the time of publication. Unsurprisingly, most Cable Street books belong to the category of historical fiction, although one of the first, Rosemary Stones and Andrew Mann's Mother Goose Comes to Cable Street (1977), is an anthology of poems celebrating children's creativity in response to the multicultural and urban environment of London's East End. While The Battle of Cable Street itself is not explored in the poems, the setting provides an unambiguously political context. The illustrator, Dan Jones, son of the artist and activist Pearl Binder and Labour Member of Parliament Elwyn Jones, has lived in Cable Street since 1967 and was involved in the creation of the Cable Street mural. Jones's images underpin the book's celebration of inclusivity.

Another example outside of historical fiction-and also produced outside the UK-shows how Cable Street is currently being used more widely to motivate activism. Facing History and Ourselves, a US-based organization with a mission to use education to explain how democracy works and to help prevent racism, bigotry, prejudice, and intolerance, includes two units on The Battle of Cable Street in its materials for teachers. The introduction to the units explains that, "by engaging with this history [of Cable Street], students will think critically about the choices made by the East End community and its allies in 1936 and then consider choices available to them as agents of change in the face of prejudice and discrimination" ("Standing Up"). In other words, The Battle of Cable Street is seen as a useful political context for helping young people today understand themselves as implicated in the way events in the world around them play out. These materials identify them as "agents of change" and, indeed, young people are increasingly giving voice to their concerns about the kind of world they will inherit. They are speaking out and demonstrating about issues such as climate change, gun control, and Black Lives Matter, meaning there is greater awareness of youth activism now than at any time since the 1960s. ${ }^{7}$ 


\section{Controlling the Cable Street Context}

Facing History and Ourselves is an independent organization that offers materials for free and provides professional development outside mainstream educational systems. This is worth noting because since the student protests in the late 1960s and early 1970s, there has been considerable concern by governments in many countries to prevent classrooms from fostering radicalism in the young as well as efforts to contain student activism (Woodman). State-run and -financed schools are discouraged from celebrating youthful engagement with politics and especially activism. In Britain, this resulted in a refusal by many schools to condone pupils' participation in the Fridays for Future climate change school strikes in 2019. The close ties between education and the children's publishing industry mean that publishers too must tread a fine line between providing topical, challenging books and the judgment of the various "gatekeepers" who exercise control over what is considered acceptable and so appropriate for classrooms and school libraries. Acceptability no doubt contributes to a writer's decision to set a radical work in Cable Street: historical distance allows what might otherwise be contentious attitudes and behaviors to be deemed acceptable, or at least to go undetected.

The Facing History units reproduce historical records, including eyewitness testimony, memoirs, reportage, and legal proceedings. Many of the same materials inform fictional accounts of The Battle of Cable Street for children and young people, but how far they encourage readers to position themselves alongside the protestors is influenced by the political contexts in which they are published. A high degree of circumspection is found, for instance, in Alan Gibbons's Street of Tall People. Published in 1995, it retells the events leading up to The Battle of Cable Street more than half a century after they occurred. Gibbons is a self-proclaimed activist for the left, so his decision to write about an incident that is claimed as a significant victory for both the left and working people is unsurprising. Neither is it surprising, given the then Conservative government's determination to repress left-wing activism and policies in schools (Pilcher and Wagg), is the way Gibbons turns the two boys at its center into witnesses to history rather than participants in it. Gibbons was writing at a time not just of overt governmental hostility to progressive teachers, teaching unions, and civil servants, but also to publishers' fears about declines in sales of children's books to libraries, school libraries, and families (Pilcher and Wagg). 
The book begins by introducing twelve-year-old Jimmy, who lives with his mother in one of the poorest parts of London's East End. He meets an Orthodox Jewish boy named Benny in the boxing ring. Ordinarily, Jews and Gentiles in the area do not mix, but the boys strike up a strong friendship. They meet shortly before Mosley's planned march through the East End, something of which Jimmy and the people he lives among are largely unaware. The boys want to help their neighbors try to stop the Mosley march, but they arrive after the Blackshirts have retreated. This means that they are never involved in the action; indeed, Street of Tall People fails to mention that children participated in the events. At one point, Benny's older sister and her fiancé are seen manning a first aid station, but there is no reference to the Trafalgar Square demonstration or the role of young people in helping to orchestrate the resistance to the police and the fascists.

Although the book seems as if it is going to focus on the antifascist achievement of those who protested in and around Cable Street, when the Battle begins it abruptly turns its attention to the multicultural nature of the Cable Street context. This requires a significant shift in the characterization of Jimmy and Benny. Until the Battle, they are shown as independent and capable. Jimmy is one of the best boxers at his club and Benny is clever and ambitious; together they start to make changes to relationships in their neighborhood. When they finally get to the streets where the fighting is taking place, however, youth and vulnerability become their defining features. Indeed, the book's title contrasts their small size with the height of the adult protestors: "He saw the bearded Jews standing shoulder-to-shoulder with people who'd never seen the inside of a synagogue in their lives. There were no Jews or goyim, only people; a street of tall people" (105). As with children at the time, the boys climb a lamppost where they can see what's going on, including red flags and a banner proclaiming "They Shall Not Pass!" The banner was presumably intended for the Trafalgar Square rally, but neither the rally nor the slogan's connection to the war in Spain is discussed.

The lamppost, the banners, and many other details in the book are evidence that Alan Gibbons did considerable research into the events and how young people were involved, but though Benny and Jimmy are indisputably on the side of the locals, they are not marble and pepper-dust throwers and they do not use their vantage point to direct the crowds. Instead, they follow behind events, through broken glass and past overturned trucks, smashed furniture, and debris of all 
sorts. Several people tell Jimmy and Benny to go home because "This is no place for children" and "This could turn nasty" (103). The boys learn the truth of these words and also that the fighting has not been with the Blackshirts but with the police when the police make another charge and nearly trample Benny. The boys have to be rescued by an adult who must then leave the protest to return them to their families. Superficially, Jimmy and Benny appear to have been stripped of messianic attributes, but that ignores the book's shift in focus from fighting fascism to encouraging inclusivity. They witness the collaboration of different social groups to prevent the fascists marching, and through their escapade they bring their families together.

Although Street of Tall People discourages children from becoming involved in demonstrations and protests, it shows they have a role to play in reducing tension between different racial, religious, and ethnic groups and helping to celebrate the multicultural nature of modern Britain. At the level of families and friendships, then, they are helping to bring about social change. That said, any parallels Alan Gibbons may have seen between Cable Street in 1934 and the rise in the 1980s and 1990s of the right-wing British National Party, which spread its message through Mosley-like marches, failed to find their way into the published book. Instead, the political context recedes into the background in favor of a traditional children's literature trope: children show grown-ups the error of their ways, in this case by making friendships that ignore social barriers based on prejudice and ignorance. Gibbons claims it was necessary to write the story in this way because of the age of his readers, but the political and publishing contexts of 1995 will also have served as a brake on the extent to which he could use Cable Street as an introduction to left-wing politics and political activism (private email). Publishers who wanted to sell into the important school market had to be careful not to produce books that would run counter to the prevailing mood (Clark and Phillips).

\section{Cable Street Reactivated}

Twenty years after Street of Tall People, two books about Cable Street were published that do offer readers activist role models in the form of young people whose passion, courage, and involvement in the events in Cable Street and the Spanish civil war make a difference: Lydia Syson's A World Between Us (2012) and Joan Lingard's Trouble on Cable Street (2014). The political climate in which they appeared had 
changed significantly from that of 1995 . The year 2012 saw the successful London Olympics and a great many British sporting wins, which cast a veneer of optimism and social cohesion over the country, even though Prime Minister David Cameron was having to lead a coalition government, the economy was shrinking, and Scotland was demanding a referendum on independence. Additionally, arguments between those who supported and those who opposed Britain's membership of the European Union were causing serious social discord; and for the first time since the end of World War II, the majority of young people were not surpassing the educational and economic attainments of their parents, yet they were also paying large fees for higher education that for their parents' generation had been subsidized. The political quiescence that had characterized the nation during the economic boom years (1995-2007) was dissipating, and there was a renewal of youth activism, particularly around student debt. Given these circumstances and their unmistakable echoes of the 1930s, it is not surprising to see interest in The Battle of Cable Street and a desire for children to redeem the future resurfacing. ${ }^{8}$

There are many similarities between Syson's and Lingard's YA novels: both are invested in showing the young as capable of understanding and participating in political events. Both begin with The Battle of Cable Street and connect it to idealistic young Britons' involvement in the conflict in Spain. Both show young women as equally important and courageous as young men in their opposition to fascism, oppression, and injustice. To avoid repetition and because Lingard's book makes more use of Cable Street, Trouble on Cable Street is the focus for the final part of this discussion.

Lingard's young characters resist the efforts of the Blackshirts to cultivate support in the Cable Street area; they are also champions of the Republicans in Spain. These two strands are intertwined in ways that celebrate youthful idealism, passion, and commitment without suggesting that these qualities will guarantee success. Lingard has considerable experience of writing about young people caught up in sectarian conflicts. She is best known for her five Kevin and Sadie novels from the 1970s, which are among the few to deal with "the Troubles" in Northern Ireland. In them, Catholic Kevin and Protestant Sadie begin as staunch supporters of their own communities, but gradually their encounters shift from hostile to sympathetic and eventually to romantic. Their activism is on a local and empathetic level, though especially in Across the Barricades (1972), it is also caught up in the wider hostilities. 
They suffer for their relationship but are morally and emotionally strong. By extension, these qualities and their unflagging resolution are projected onto youth as a category in line with the redemptive qualities of Benjamin's messianic child figure. Like Jimmy and Benny, they model good relationships across hostile groups.

Trouble on Cable Street paints an informed and empathetic picture of young people growing up in times of conflict and making a difference. In this book, activism means standing up for what you believe in; being informed and educated and committing to your beliefs in the service of others, irrespective of age, sex, nationality, religion, or ethnicity. The Battle of Cable Street is not at the center of the novel; it takes place in the opening pages of the book and is rarely referred to again. However, as a political context it does a tremendous amount of work. For instance, it shows today's young readers how volatile the situation then was, both locally and globally. At the same time, it provides historical background to readers growing up in and appreciating today's multicultural Britain but regularly encountering misinformation about high levels of immigration and refugees.

Lingard immediately establishes that the Cable Street area is populated with migrants from many parts of the world. The central character, Isabella (Izzie), has a Spanish mother; her best friend is Irish; and Izzie works as a seamstress for a Jewish refugee from Nazi Germany. Nearly sixteen, Izzie has been working since she was fourteen-like all the young people in the area who can find work in Depression-era Britain. At the start of the book, her seventeen-year-old brother Will is preparing to leave to fight in Spain. The links between young people involved in The Battle of Cable Street and those who volunteered for the International Brigades is established when Izzie's family helps a Scottish boy who was planning to go to Spain but is injured by the police during the fighting around Cable Street.

All the action in this book, both at home and in Spain, is done by young people; there is no question of whether it is appropriate for them to be involved. Young people are working to change the tide of events, actively affecting politics at home and abroad—and The Battle of Cable Street is both a catalyst for and the glue that binds their actions. Although Izzie is not an activist organizer, she participates in the Battle, and crucially, she carries on its work of opposing Mosley and trying to improve life for the people in her area.

Another significant factor in the book is the importance Izzie places on education. After work she attends a night school, and her ability 
to act and to discriminate between causes are grounded in her welltrained and informed mind. For budding activists, this is arguably the most important lesson in the book. It is used to show how the energy, passion, and ideals of the young can be caught up in perverted causes if they lack the ability to interrogate arguments and the moral compass that distinguishes between right and wrong. Izzie's less-educated older brother becomes, for a time, a "useful idiot" in the service of the Blackshirts, though he has the courage to disown them when he learns to see them clearly. Today's children and young people are required to distinguish between screeds of both reliable and distorted information from social media as well as more traditional forums. The overwhelming nature of the messages that bombard them, together with the lingering perception that the young should be shielded from troubling issues rather than part of social redemption, goes some way toward explaining the turn-of-the-millennium shift from radical literature to messianic fantasies, with their lack of focus on practical ways politically engaged young people can help to bring about positive change. Its historical setting means Trouble on Cable Street does not offer guidance on managing the current situation; nevertheless, the book's general advice about the importance of education, the need to find trustworthy sources and mentors, and how easy it can be to be misled by charismatic and forceful personalities is as relevant now as it has ever been.

Fiction's ability to draw readers in and to explore why characters do certain things, how they feel about them, and the consequences of their actions makes it a powerful part of social education and personal development. In our media-rich age, it remains important that the young have well-informed fiction that addresses specific political contexts and takes readers through the challenges, dilemmas, and setbacks that are an inevitable part of opposing official policies or the business practices of powerful corporations. Most countries will have their own key moments that, like The Battle of Cable Street, provide an effective background for the activism of young people in the past. As well as learning from the past, however, young readers need books that speak directly about their own political context. It is particularly welcome, then, that the current publishing climate is more receptive to radical children's literature than it has been for decades. ${ }^{9}$ A good barometer of this change in the UK is the Little Rebels Children's Book Award, established in 2010 by the Alliance of Radical Booksellers and Letterbox Library, a children's publisher that specializes in children's books that promote equality and diversity. Year on year, the number and 
quality of books entered has grown rapidly (as a judge from 2011-14, I witnessed the immediate impact of the award firsthand). Although they focus on a range of issues, individuals, and historical moments, collectively these new contributions to radical children's literature show that the political arena needs the young. More importantly, far from the vagaries of messianic fantasy, they help young readers see themselves as instrumental to bringing about social change at home and as part of global movements.

\section{Notes}

${ }^{1}$ See Pfeffer; and Demissie and Iglikowski.

${ }^{2}$ For example, Chowdhury; Nikolajeva; and Reynolds, "Child Hating."

${ }^{3}$ See, among others, Nel; Mickenberg and Nel; Reynolds, Radical Children's Literature, Reynolds, Left Out; Reynolds, "Radical Reading"; Reynolds, "Reading for Little Rebels"; and Reynolds, Rosen, and Rosen.

${ }^{4}$ This process is clearly visible in both the 1948 United Nation General Assembly's Universal Declaration of Human Rights, which makes special provision for the protection and care of children, and its 1959 Declaration of the Rights of the Child, both precursors to the 1989 Convention on the Rights of the Child (see "History of Child Rights").

${ }^{5}$ The YCL was the Youth Section of the British Communist Party. Formed in 1921, its members included pupils and young workers, ranging in age from nine to thirty.

${ }^{6}$ Extracts and additional examples can be read in Reynolds, Rosen, and Rosen.

${ }^{7}$ Media reports indicate that youth activism on these issues is widespread. An indicative sample of coverage on these topics includes 1) a summary of youth activism before the UN Climate Change Summit in September 2019 (see "Global Climate Strikes"); 2) the student-led March for Our Lives in March 2018 (see Lopez); and 3) information on child activists and Black Lives Matter (see Hemenway).

${ }^{8}$ In "Radical Reading," I discuss the current increase in radical children's literature that moves well beyond the Cable Street context.

${ }^{9}$ I place The Little Rebels Award in the wider context of radical children's literature in my 2018 lecture. See Reynolds, "Reading for Little Rebels."

\section{Works Cited}

Chowdhury, Radhiah. "A Chosen Sacrifice: The Doomed Destiny of the Child Messiah in Late Twentieth-Century Children's Fantasy." Papers: Explorations into Children's Literature, vol. 16, no. 2, Dec. 2006, pp. 107-11.

Clark, Giles, and Angus Phillips. Inside Book Publishing. 5th ed., Routledge, 2014.

Demissie, Simon, and Vicky Iglikowski-Broad. "No pasarán': The Battle of Cable Street." National Archives Blog, 4 Oct. 2016, blog.nationalarchives.gov.uk/no-pasaran-battlecable-street.

Gibbons, Alan. Private email. Received by author. 20 Apr. 2019. . Street of Tall People. Orion, 1995.

Gillan, Audrey. "[The] Day the East End said 'No pasarán' to Blackshirts." The Guardian, 30 Sept. 2006, www.theguardian.com/uk/2006/sep/30/thefarright.past.

"Global Climate Strikes: Millions of Children Take Part in Protests to Help Protect the Planet." Newsround, BBC, 20 Sept. 2019, www.bbc.co.uk/newsround/49766020.

Hemenway, Justin. "Young Activists Stand Up for Justice at Black Lives Matter Protests." UNICEF USA, 11 Sept. 2020, www.unicefusa.org/stories/young-activists-stand-justiceblack-lives-matter-protests/37607. 
"History of Child Rights." UNICEF, 16 Apr. 2019, www.unicef.org/child-rights-convention/history-child-rights.

Jacobs, Joe. "The Battle of Cable Street." Libcom.org, libcom.org/files/The\%20Battle\%20 of\%20Cable\%20St,\% 201936\% 20-\% 20Joe\%20Jacobs.pdf. Originally published in Out of the Ghetto, Janet Simon, 1978.

Jessop, Sharon. "Children, Redemption and Remembrance in Walter Benjamin." Journal of Philosophy of Education, vol. 47, no. 4, Dec. 2013, pp. 642-57, www.researchgate. net/publication/259544771_Children_Redemption_and_Remembrance_in_Walter_Benjamin.

Lingard, Joan. Trouble on Cable Street. Catnip, 2014.

Lopez, German. "It's Official: March for Our Lives Was One of the Biggest Youth Protests since the Vietnam War." Vox, 26 Mar. 2018, www.vox.com/policy-and-politics/2018/3/26/17160646/march-for-our-lives-crowd-size-count.

Martin's Annual. Edited by Joan Beauchamp, Martin Lawrence, 1934.

Mickenberg, Julia L., and Philip Nel. "Radical Children's Literature Now!" Children's Literature Association Quarterly, vol. 36, no. 4, Winter 2011, pp. 445-73.

Nel, Philip. "A Manifesto for Radical Children's Literature (and an Argument Against Radical Aesthetics)." Barnboken: Journal of Children's Literature Research, vol. 42, 2019, pp. $1-25$.

Nikolajeva, Maria. "Harry Potter and the Secrets of Children's Literature." Critical Perspectives on Harry Potter, edited by Elizabeth E. Heilman, Routledge, 2008, pp. 225-42.

Osborne, Peter, and Matthew Charles. "Walter Benjamin." The Stanford Encyclopedia of Philosophy, edited by Edward N. Zalta, Winter 2019, plato.stanford.edu/entries/benjamin.

Pfeffer, Anshel. "The Battle of Cable Street and Other British Jewish Myths." HAARETZ, 7 Oct. 2016, www.haaretz.com/opinion/the-battle-of-cable-street-and-other-britishjewish-myths-1.5446805.

Pilcher, Jane, and Stephen Wagg. Thatcher's Children?: Politics, Childhood and Society in the 1980s and 1990s. Falmer, 1996.

The Red Corner Book for Children. Martin Lawrence, 1931.

Reynolds, Kimberley. "Child Hating and Dystopian Fiction." The Modern Scholar: Children's Literature Between the Covers, narrated by Kimberley Reynolds, audiobook, ed, Recorded Books, 2011.

. Left Out: The Forgotten Tradition of Radical Publishing for Children in Britain, 1910-1949. Oxford UP, 2016.

. Radical Children's Literature: Future Visions and Aesthetic Transformations in Juvenile Fiction. Palgrave Macmillan, 2007.

. "Radical Reading and Radical Writing: Remaking Children's Literature." Culture Matters, 12 May 2016, culturematters.org.uk/index.php/arts/fiction/item/2300radical-reading-and-radical-writing-remaking-children-s-literature.

"Reading for Little Rebels: Internationalism and Radical Writing for Children." Institute for Advanced Studies Public Lectures. University of West Australia, 2018, www.ias.uwa.edu.au/lectures/kimberleyreynolds.

Reynolds, Kimberley, Jane Rosen, and Michael Rosen, editors. Reading and Rebellion: An Anthology of Radical Writing for Children 1900-1960. Oxford UP, 2018.

Rosen, Jane. "Which Side Are You On?': Children as Trade Union Activists in Radical and Mainstream Children's Literature." Activism and Empathy, Children's Literature Association Conference, 13 June 2018, Westin Hotel, Indianapolis, IN.

Ross, Alison. "Walter Benjamin's Idea of Revolution: The Fulfilled Wish in Historical Perspective." Cogent Arts and Humanities, vol. 4, no. 1, 2017, www.tandfonline.com/ doi/full/10.1080/23311983.2017.1390919.

"Standing Up to Hatred on Cable Street." Facing History and Ourselves, www.facinghistory. org/resource-library/standing-democracy/standing-hatred-cable-street.

Stones, Rosemary, and Andrew Mann. Mother Goose Comes to Cable Street. Illustrated by Dan Jones, Kestrel, 1977. 
Syson, Lydia. A World Between Us. Hot Key, 2012.

Valman, Nadia. "Pepper to Throw at Fascists: The Forgotten Women of Cable Street." New Statesman, 4 Oct. 2016, www.newstatesman.com/politics/feminism/2016/10/ pepper-throw-fascists-forgotten-women-cable-street.

Woodman, Connor. "The Repression of Student Movements in the UK." Pluto Press Blog, 17 Oct. 2017, www.plutobooks.com/blog/repression-student-movements-uk.

Zipes, Jack. "Walter Benjamin, Children's Literature, and the Children's Public Sphere: An Introduction to New Trends in West and East Germany." New Approaches to Children's Literature, special issue of The Germanic Review, vol. 63, no. 1, Jan. 1988, www.researchgate.net/publication/232948388_Walter_Benjamin_Children's_Literature_and_the_Children's_Public_Sphere_An_Introduction_to_New_Trends_in_ West_and_East_Germany. 